\title{
Solid-state production of polygalacturonase by Aspergillus sojae ATCC 20235
}

\author{
Fatma Isık Ustok ${ }^{\mathrm{a}}$, Canan Tari ${ }^{\mathrm{b}, *}$, Nihan Gogus ${ }^{\mathrm{b}}$ \\ a Biotechnology and Bioengineering Programme, Izmir Institute of Technology, Urla, Izmir 35430, Turkey \\ ${ }^{\mathrm{b}}$ Department of Food Engineering, Izmir Institute of Technology, Urla, Izmir 35430, Turkey
}

Received 12 May 2006; received in revised form 16 June 2006; accepted 7 July 2006

\begin{abstract}
The effect of solid substrates, inoculum and incubation time were studied using response surface methodology (RSM) for the production of polygalacturonase enzyme and spores in solid-state fermentation using Aspergillus sojae ATCC 20235. Twostage optimization procedure was applied using D-optimal and face-centered central composite design (CCD). Crushed maize was chosen as the solid substrate, for maximum polygalacturonase enzyme activity based on D-optimal design. Inoculum and incubation time were determined to have significant effect on enzyme activity and total spore $(p<0.01)$ based on the results of CCD. A second order polynomial regression model was fitted and was found adequate for individual responses. All two models provided an adequate $R^{2}$ of 0.9963 (polygalacturonase) and 0.9806 (spores) $(p<0.001)$. The individual optimum values of inoculum and incubation time for maximum production of the two responses were $2 \times 10^{7}$ total spores and 5-6 days. The predicted enzyme activity $(30.55 \mathrm{U} / \mathrm{g}$ solid $)$ and spore count $\left(2.23 \times 10^{7} \mathrm{spore} / \mathrm{ml}\right)$ were very close to the actual values obtained experimentally $\left(29.093 \mathrm{U} / \mathrm{g}\right.$ solid and $2.31 \times 10^{7} \mathrm{spore} / \mathrm{ml}$, respectively). The overall optimum region considering the two responses together, overlayed with the individual optima. Solid-state fermentation provided $48 \%$ more polygalacturonase activity compared to submerged fermentation under individually optimized conditions.
\end{abstract}

(c) 2006 Elsevier B.V. All rights reserved.

Keywords: Aspergillus sojae; Polygalacturonase; Solid-state fermentation; Response surface methodology

\section{Introduction}

Enzyme production which is a growing field of biotechnology has an annual world sales close to a bil-

\footnotetext{
* Corresponding author. Tel.: +90 2327506316 ; fax: +90232 7506196 .

E-mail addresses: ctari7@yahoo.com, canantari@iyte.edu.tr (C. Tari).
}

lion dollars together with increasing number of patents and research articles (Layman, 1990; Gonzales et al., 2003). Even though most of the enzyme manufactures produce enzymes by means of submerged fermentation $(\mathrm{SmF})$ techniques, there is recently a significant interest in using solid-state fermentation (SSF) instead (Pandey et al., 1999; Gonzales et al., 2003). The reason behind this, is cited by the advantages that this technique (SSF) has over SmF. These are listed as higher 
productivity per reactor volume, lower capital costs, less space requirements, simpler equipment and easier downstream processing (Pandey et al., 2000; Martins et al., 2002). Another very important advantage is that, it permits the use of agricultural and agro-industrial residues as substrates which are converted into bulk chemicals and into products with high commercial value like organic acids, proteins, alcohol and enzymes (Manonmani and Sreekantiah, 1987; Spangnuolo et al., 1997; Martins et al., 2002). Furthermore, the utilization of these compounds helps in solving pollution, which otherwise cause their disposal (Couto and Sanroman, 2005; Pandey et al., 1999).

Large numbers of microorganisms, including bacteria, yeast and fungi can be used in SSF systems. Selection of a particular strain, however, remains a tedious task depending upon a number of factors, like the nature of the substrate, environmental conditions and the desired final product. Filamentous fungi are the best-adapted species of SSF and dominate in research and practical application around the world. This can be attributed to the advantage of the hyphal mode of growth with the colonization on solid substrates and utilization of variable substrates (Knapp and Howell, 1980).

Pectinases or pectinolytic enzymes (polygalacturonase, pectin methylesterase, pectin lyase) which are well known with their commercial significance among the enzymes, are mainly produced using SSF technique. Pectinases which hold a share of $25 \%$ in the global sales of food enzymes (Jayani et al., 2005), are widely used in the beverage industry due to their ability to improve pressing and clarification of concentrated fruit juices. Besides, they are used in processing of fruits and vegetables, in the production of wine, in the extraction of olive oil and fermentation of tea and coffee (Castilho et al., 2000; Silva et al., 2005). Furthermore, they find applications in paper and pulp industry, waste management, animal feed and textile industry (Silva et al., 2002).

Among the pectinases used, polygalacturonase produced by Aspergillus niger is the most studied one with commercial significance (Castilho et al., 2000; Couto and Sanroman, 2005). However, to best of our knowledge there is no available literature on the production of this enzyme (polygalacturonase) by Aspergillus sojae in either mode (SSF or SmF), which makes this study extra novel.
In order to determine the potential of this strain, and contribute to the literature by filling this gap, a study was initiated using A. sojae ATCC 20235 in the production of the polygalacturonase from here on PG, which has a highly commercial value. With our previous study on submerged fermentation using this organism we proved that this organism has a good potential for PG synthesis with the desired pellet morphology (Gogus et al., 2006). Therefore, it was worth wide to determine if this potential could be increased using SSF. Together with the high enzyme productivity in SSF, the production of high spore counts obtained through this technique, is of great significance for industrial submerged fermentations requiring spore inoculations.

With this perspective, using statistical tools (RSM), these responses were optimized, first independently and later together with respect to the factors of source of solid substrate, inoculum and incubation time. As it is well known these factors are highly significant in SSF (Sangeetha et al., 2004; Couto and Sanroman, 2005) and very specific to every single strain. In solidstate fermentations, the selection of a suitable solid substrate for a fermentation process is a critical factor. The selection of suitable substrates for pectinase production has mainly been centered on tropical agroindustrial crops and residues. Among these are wheat bran, rice bran, apple pomace, orange bagasse, sugar cane bagasse, the most studied ones (Maldonado and Strasser de Saad, 1998; Bai et al., 2004). However, there is no study on the interaction of these substrates with factors like inoculum and incubation time, which are of primary importance in solid-state fermentations. With this perspective, inoculum $\left(X_{1}\right)$ and incubation time $\left(X_{2}\right)$ as quantitative variables, corncob, maize meal and crushed maize which are produced in surplus quantities worldwide (Kunamneni and Singh, 2005), as qualitative variables $\left(X_{3}\right)$ were taken for the optimization, using RSM for maximum PG activity and total spore generation.

Although the main focus of this paper is on SSF, a brief comparison on enzyme titers between the optimized conditions of SmF and SSF are given at the end.

The results of this study by introducing a strain with a new application mode in the production of a highly valuable enzyme, is thought to be beneficial to the enzyme industry, food industry and the microbiology area. 


\section{Materials and methods}

\subsection{Microorganism}

A. sojae ATCC 20235 (from here on A. sojae only for simplicity) was purchased in the lyophilized form, from Procochem Inc., an international distributor of ATCC (American Type of Culture Collection) in Europe. The propagation of this culture was done on YME agar slant medium containing, malt extract $(10 \mathrm{~g} / \mathrm{l})$, yeast extract $(4 \mathrm{~g} / \mathrm{l})$, glucose $(4 \mathrm{~g} / \mathrm{l})$ and agar $(20 \mathrm{~g} / \mathrm{l})$, incubated at $30^{\circ} \mathrm{C}$ until well sporulation ( 1 week). Stock cultures of these strains were prepared with $20 \%$ glycerol water and stored at $-80^{\circ} \mathrm{C}$.

\subsection{Seed inoculum}

The spore suspensions used as inoculum were obtained on molasses agar slants containing: glycerol $(45 \mathrm{~g} / \mathrm{l})$, peptone $(18 \mathrm{~g} / \mathrm{l})$, molasses $(45 \mathrm{~g} / \mathrm{l})$, $\mathrm{NaCl} \quad(5 \mathrm{~g} / \mathrm{l}), \quad \mathrm{FeSO}_{4} \cdot 7 \mathrm{H}_{2} \mathrm{O} \quad(15 \mathrm{mg} / \mathrm{l}), \quad \mathrm{KH}_{2} \mathrm{PO}_{4}$ $(60 \mathrm{mg} / \mathrm{l}), \mathrm{MgSO}_{4}(50 \mathrm{mg} / \mathrm{l}), \mathrm{CuSO}_{4} \cdot 5 \mathrm{H}_{2} \mathrm{O}(12 \mathrm{mg} / \mathrm{l})$, $\mathrm{MnSO}_{4} \cdot \mathrm{H}_{2} \mathrm{O}(15 \mathrm{mg} / \mathrm{l})$ and agar $(20 \mathrm{~g} / \mathrm{l})$, after the pre-activation step performed on YME agar using the stock cultures. The incubation temperature and time for each of the steps were $30^{\circ} \mathrm{C}$ and 1 week, respectively. The harvesting of the spores from the slants was done using $5 \mathrm{ml}$ of Tween 80 water $(0.02 \%)$. The spore suspension was collected in sterile falcon tube and stored at $4{ }^{\circ} \mathrm{C}$ until the actual study. The initial spore counts and viability counts were recorded.

The inoculum for the actual solid-state fermentation was prepared by transferring the predefined amounts of spore solutions corresponding to the ranges of $2.5 \times 10^{5}$ to $7.5 \times 10^{5}$ total spores (for D-optimal design) and $1.25 \times 10^{4}$ to $2 \times 10^{7}$ total spores (for CCD design), into $250 \mathrm{ml}$ Erlenmeyer flasks containing $50 \mathrm{ml}$ sterile molasses broth (composition as defined above excluding the agar).

\subsection{Solid-state fermentation}

Solid-state fermentation was carried out in a $500 \mathrm{ml}$ Erlenmeyer flasks containing $50 \mathrm{~g}$ of either one of the sterilized solid substrates $\left(121^{\circ} \mathrm{C} / 15 \mathrm{~min}\right)$, such as crushed maize, maize meal or corncob obtained from a local company (Sunar Misir Inc.). These were inoculated with the inoculum medium, prepared as stated

Table 1

D-optimal design and experimental results of polygalacturonase (PG) activity and spore production in SSF

\begin{tabular}{llllll}
\hline $\begin{array}{l}\text { Running } \\
\text { order }\end{array}$ & $\begin{array}{l}\text { Variable, } X_{1} \\
\text { (inoculum (total } \\
\text { spores) }\end{array}$ & $\begin{array}{l}\text { Variable, } X_{2} \\
\text { (incubation time } \\
(\text { day) })\end{array}$ & $\begin{array}{l}\text { Variable, } X_{3} \text { (solid } \\
\text { substrate) }\end{array}$ & $\begin{array}{l}\text { Response 1 (total } \\
\text { spores (number)) }\end{array}$ & $\begin{array}{l}\text { Response 2 } \\
\text { (enzyme activity } \\
\text { (U/g solid) }\end{array}$ \\
\hline 1 & $2.50 \times 10^{5}$ & 10 & Corncob & $3.65 \times 10^{9}$ & 0.27 \\
2 & $7.50 \times 10^{5}$ & 10 & Corncob & $2.09 \times 10^{9}$ & 0.21 \\
3 & $2.50 \times 10^{5}$ & 10 & Maize meal & $2.48 \times 10^{8}$ & 0.10 \\
4 & $2.50 \times 10^{5}$ & 10 & Corncob & $3.27 \times 10^{9}$ & 0.22 \\
5 & $7.50 \times 10^{5}$ & 10 & Maize meal & $1.13 \times 10^{8}$ & 2.20 \\
6 & $7.50 \times 10^{5}$ & 10 & Maize meal & $1.73 \times 10^{8}$ & 1.43 \\
7 & $7.50 \times 10^{5}$ & 6 & Maize meal & $2.70 \times 10^{8}$ & 2.83 \\
8 & $2.50 \times 10^{5}$ & 6 & Corncob & $3.55 \times 10^{9}$ & 0.18 \\
9 & $5.00 \times 10^{5}$ & 10 & Crushed maize & $6.13 \times 10^{8}$ & 4.12 \\
10 & $7.50 \times 10^{5}$ & 6 & Crushed maize & $6.50 \times 10^{8}$ & 4.63 \\
11 & $7.50 \times 10^{5}$ & 10 & Corncob & $1.52 \times 10^{9}$ & 0.13 \\
12 & $2.50 \times 10^{5}$ & 6 & Crushed maize & $1.05 \times 10^{9}$ & 4.16 \\
13 & $7.50 \times 10^{5}$ & 6 & Corncob & $1.87 \times 10^{9}$ & 0.16 \\
14 & $5.00 \times 10^{5}$ & 8 & Maize meal & $1.39 \times 10^{8}$ & 1.78 \\
15 & $7.50 \times 10^{5}$ & 8 & Crushed maize & $4.50 \times 10^{8}$ & 4.81 \\
16 & $2.50 \times 10^{5}$ & 6 & Maize meal & $3.13 \times 10^{8}$ & 2.47 \\
17 & $5.00 \times 10^{5}$ & 7 & Corncob & $4.00 \times 10^{9}$ & 0.17 \\
18 & $5.00 \times 10^{5}$ & 10 & Crushed maize & $8.66 \times 10^{8}$ & 0.09 \\
19 & $5.00 \times 10^{5}$ & 6 & Crushed maize & $1.12 \times 10^{9}$ & 3.61 \\
20 & $2.50 \times 10^{5}$ & 8 & Crushed maize & $7.68 \times 10^{8}$ & 5.48 \\
\hline
\end{tabular}

${ }^{a}$ Mean of three values, S.D. within $10 \%$. 
in Section 2.2 according to the experimental designs shown in Tables 1 and 3 and mixed thoroughly. The contents were incubated at $30^{\circ} \mathrm{C}$ between 3 and 10 days as prescribed by the same experimental designs. The final moisture content of the flasks before the incubation period were approximately 48.99\%, 51.04\%, $50.69 \%(\mathrm{w} / \mathrm{w})$ for crushed maize, maize meal and corncob, respectively. In order to control the humidity of the incubator an additional flask full of water was placed inside.

\subsection{Enzyme extraction}

At the end of the specified incubation periods, $150 \mathrm{ml}$ of sterile Tween 80 water $(0.02 \%)$ was added into each Erlenmeyer flask and stirred in a shaker at $150 \mathrm{rpm}$ at $30^{\circ} \mathrm{C}$ for $30 \mathrm{~min}$. Following this period, flasks were filtered through the sterile cheese cloth and centrifuged at $4{ }^{\circ} \mathrm{C}, 6000 \mathrm{rpm}$ for $15 \mathrm{~min}$. The supernatant and pellet were used for enzyme assay and biomass determination, respectively.

\subsection{Submerged fermentation}

For submerged fermentation a total of 31 shake flasks media (50 $\mathrm{ml}$ in $250 \mathrm{ml}$ Erlenmeyer), were prepared according to the face-centered CCD (Table 5) and run at $30^{\circ} \mathrm{C}$ for $96 \mathrm{~h}$. The basal medium consisted of glucose $(25 \mathrm{~g} / \mathrm{l})$, peptone $(2.5 \mathrm{~g} / \mathrm{l})$, disodium phosphate $(3.2 \mathrm{~g} / \mathrm{l})$ and monosodium phosphate $(3.3 \mathrm{~g} / \mathrm{l})$. To this medium, maltrin and corn steep liquor (CSL) (Cargill Sweetener and Starches Inc. and Sigma, St. Louis, MO) were added according to the concentrations given in the design. After $96 \mathrm{~h}$ of incubation, each flask was assayed for enzyme activity. Enzyme activity was determined on supernatant obtained after the centrifugation of the broth at $6000 \mathrm{rpm}$ for $15 \mathrm{~min}$.

\subsection{Enzyme assay}

Polygalacturonase (PG) activity was assayed according to the procedure given by Panda et al. (1999) using $2.4 \mathrm{~g} / \mathrm{l}$ of polygalacturonic acid as substrate at $\mathrm{pH}$ 6.6 and $26^{\circ} \mathrm{C}$. The amount of substrate and enzymes used were 0.4 and $0.086 \mathrm{ml}$, respectively. One unit of enzyme activity was defined as the amount of enzyme that catalyses the release of $1 \mu \mathrm{mol}$ of galacturonic acid per unit volume of culture filtrate per unit time at standard assay conditions. Galacturonic acid (Sigma, St. Louis, MO) was used as standard for the calibration curve of PG activity. Enzyme activity was also expressed as U/g solid substrate after dividing it to the substrate concentration $(\mathrm{g} / \mathrm{ml})$ used:

$$
\begin{aligned}
\operatorname{activity}(\mathrm{U} / \mathrm{ml})= & \frac{\mathrm{mg} \text { of galacturonic acid }}{212.12} \\
& \times \frac{1}{20} \times \frac{1}{0.086}
\end{aligned}
$$

\subsection{Biomass and spore count}

Although it was difficult to determine the biomass $(\mathrm{g} / \mathrm{l})$ in SSF accurately, it was determined gravimetrically using the pellet obtained from Section 2.4. This was dried at $30^{\circ} \mathrm{C}$ until constant weight was reached. Biomass determinations were done only for the experiments specified in CCD design. (Since, the substrate for the experiments in this section was crushed maize only and all the procedures were the same, any discrepancy arising from the substrate was not expected.) For $\mathrm{SmF}$ experiments, biomass was determined in a similar way as in SSF with only the difference that the whole fermentation broth was used for centrifugation instead of the extracted broth as in SSF. Biomass was used in the expressions of the specific activities for the comparison of the two systems (SSF and SmF).

The spore counts (spores $/ \mathrm{ml}$ ) were performed using Thoma bright line hemacytometer (Marienfield, Germany).

\subsection{Experimental design and statistical analysis}

The effects of, inoculum $\left(X_{1}\right)$, incubation time $\left(X_{2}\right)$ and solid substrate $\left(X_{3}\right)$ were investigated on the responses of PG activity and spore count using RSM in solid-state fermentation. A D-optimal statistical design with three factors and face-centered composite design (CCD) with two factors and five center points were used. A total of 20 treatment combinations in D-optimal design and 13 in face centered composite design were generated and performed. Analysis of data and generation of response surface graphics were done by the software Design Expert 6.0.11 and 7.0.0 Trial Version, Stat-Ease Inc. The response variables were PG activity and spore count for both D-optimal design and facecentered CCD design. 
In submerged fermentation the effects of independent variables, such as concentrations of maltrin $\left(X_{1}\right)$ and corn steep liquor $\left(X_{2}\right)$, agitation speed $\left(X_{3}\right)$ and inoculum $\left(X_{4}\right)$ were investigated on the responses of PG activity using RSM. A face-centered CCD design with four factors were generated and conducted. Analysis of data and generation of response surface graphics was done by Minitab statistical software (release 13).

After running the experiments and measuring the response variables, a second order polynomial equation including the interactions was fitted to the response data by multiple regression procedure:

$Y=\beta_{0}+\sum_{i=1}^{k} \beta_{i} X_{i}+\sum_{i=1}^{k} \beta_{i i} X_{i}^{2}+\sum_{i} \sum_{j} \beta_{j} X_{i} X_{j}+\varepsilon$

where $Y$ is the predicted response, $k$ the number of factor variables, $\beta_{0}$ the model constant, $\beta_{i}$ the linear coefficient, $X_{i}$ the factor variable in its coded form, $\beta_{i i}$ the quadratic coefficient, $\beta_{i j}$ the interaction coefficient and $\varepsilon$ is the error factor. The following equation is used for coding the actual experimental values of the factors in a range of $[-1+1]$ :

$x=\frac{\text { actual }-((\text { low level }+ \text { high level }) / 2)}{(\text { high level }- \text { low level }) / 2}$

The analysis of variance (ANOVA) tables were generated and the effect and regression coefficients of individual linear, quadratic and interaction terms were determined. The significances of all terms in the polynomial were judged statistically according to their $p$ values.

\section{Result and discussions}

\subsection{Solid-state fermentation}

The optimization procedure in solid-state fermentation was done in two steps. First, the selection of the suitable solid substrate for maximum PG activity and total spore count was done using D-optimal design (Table 1). In the second step, the best substrate which resulted into maximum enzyme activity (from step 1) was kept constant and two independent variables $\left(X_{1}\right.$

Table 2

ANOVA table: effect of the parameters on (a) total spore count and (b) PG enzyme activity in SSF

\begin{tabular}{|c|c|c|c|c|c|}
\hline Source & Sum of squares & d.f. & Mean (square) & $F$-Value & $p>\mathrm{F}$ \\
\hline \multicolumn{6}{|c|}{ (a) Total spore count } \\
\hline Model & $2.83 \mathrm{E}+22$ & 4 & $7.07 \mathrm{E}+21$ & 28.02 & $<0.0001$ significant \\
\hline$X_{1}$ & $2.29 \mathrm{E}+21$ & 1 & $2.29 \mathrm{E}+21$ & 9.07 & 0.0088 \\
\hline$X_{2}$ & $1.77 \mathrm{E}+20$ & 1 & $1.77 \mathrm{E}+20$ & 0.7 & 0.4152 \\
\hline$X_{3}$ & $2.50 \mathrm{E}+22$ & 2 & $1.25 \mathrm{E}+22$ & 49.46 & $<0.0001$ \\
\hline Residual & $3.78 \mathrm{E}+21$ & 15 & $2.52 \mathrm{E}+20$ & & \\
\hline Lack of fit & $3.52 \mathrm{E}+21$ & 11 & $3.20 \mathrm{E}+20$ & 4.79 & 0.0718 not significant \\
\hline Pure error & $2.67 \mathrm{E}+20$ & 4 & $6.68 \mathrm{E}+19$ & & \\
\hline Total & $3.21 \mathrm{E}+22$ & 19 & & & \\
\hline \multicolumn{6}{|c|}{ (b) PG enzyme activity in SSF } \\
\hline Model & 50.82 & 4 & 12.7 & 9.87 & 0.0004 significant \\
\hline$X_{1}$ & 0.31 & 1 & 0.31 & 0.24 & 0.6321 \\
\hline$X_{2}$ & 3.81 & 1 & 3.81 & 2.96 & 0.1059 \\
\hline$X_{3}$ & 41.12 & 2 & 20.56 & 15.97 & 0.0002 \\
\hline Residual & 19.3 & 15 & 1.29 & & \\
\hline Lack of fit & 10.86 & 11 & 0.99 & 0.47 & 0.8561 not significant \\
\hline Pure error & 8.45 & 4 & 2.11 & & \\
\hline Total & 70.12 & 19 & & & \\
\hline
\end{tabular}

$X_{1}$ : inoculum; $X_{2}$ : incubation time; $X_{3}$ : solid substrate. 
and $X_{2}$ ) were optimised using $2^{2}$ face centered CCD design as mentioned in Section 2.8.

\subsubsection{First step optimization (D-optimal design)}

In the first part of this section the aim was to determine the factors affecting the total spore counts and PG synthesis which have industrial importance in spore preparation steps of submerged fermentations. It is of great significance to produce large amount of spores on solid substrates and harvest these later as inoculum. This requires lots of time, material and effort when large-scale fermentations are considered. Therefore, determining the suitable solid substrate and the conditions (e.g. inoculum and incubation time) favour-
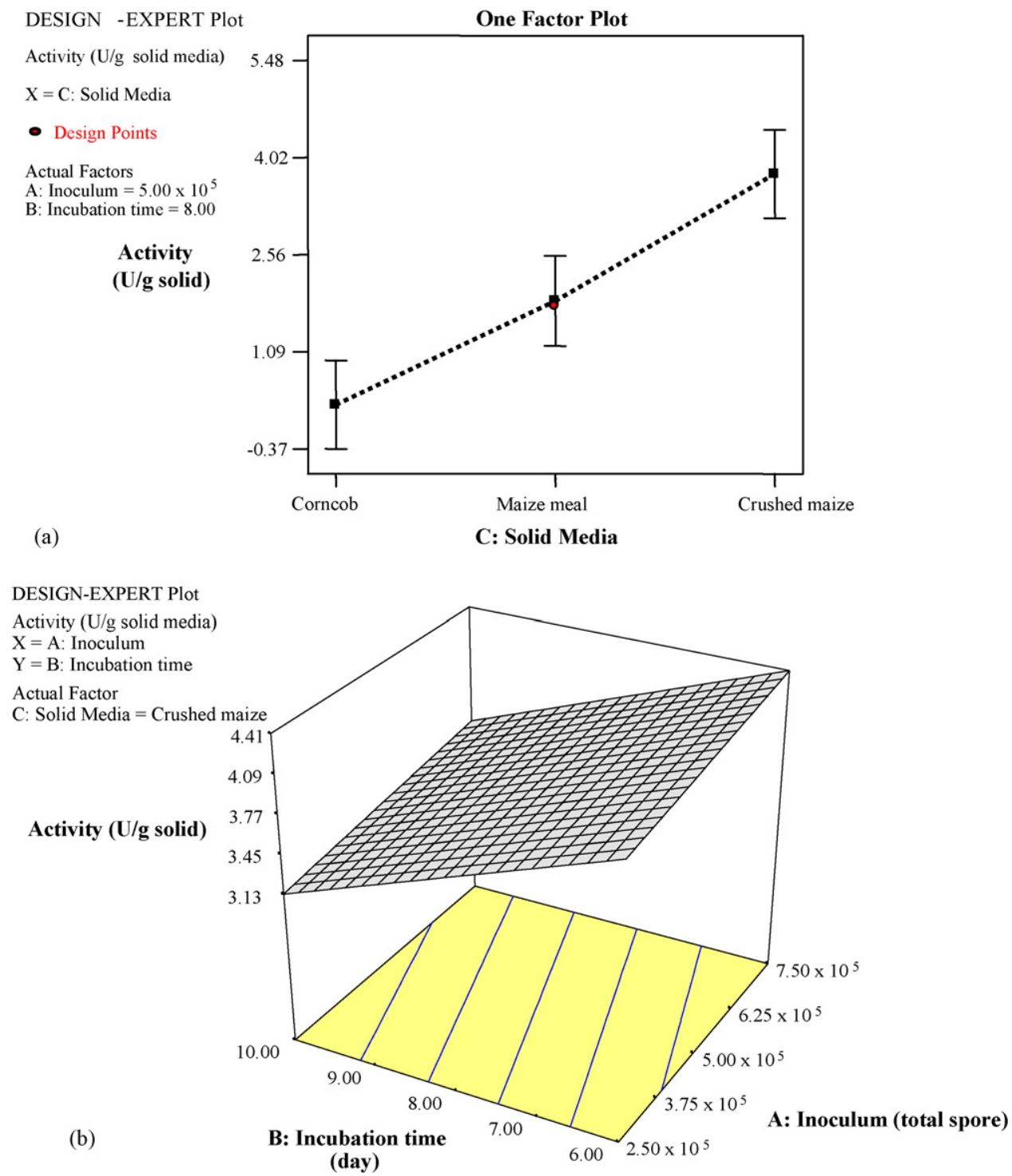

Fig. 1. D-optimal design for PG activity: (a) one factor plot using three different solid substrates at an inoculum of $5 \times 10^{5}$ total spores and incubation time of 8 days and (b) response surface graph showing the interaction effect of incubation time and inoculum on the PG enzyme activity using crushed maize as solid substrate. 
Table 3

Central composite design and experimental results of PG enzyme activity and spore count in SSF

\begin{tabular}{lllll}
\hline $\begin{array}{l}\text { Running } \\
\text { order }\end{array}$ & $\begin{array}{l}\text { Factor, } X_{1} \text { (inoculum } \\
\text { (total spores)) }\end{array}$ & $\begin{array}{l}\text { Factor, } X_{2} \text { (incubation } \\
\text { time (day)) }\end{array}$ & $\begin{array}{l}\text { Response 1 (enzyme } \\
\text { activity (U/g solid)) }\end{array}$ & $\begin{array}{l}\text { Response 2 (spore } \\
\text { count (spore/ml)) }\end{array}$ \\
\hline 1 & $1.00 \times 10^{7}$ & 6 & 17.37 & $8.80 \times 10^{6}$ \\
2 & $1.00 \times 10^{7}$ & 6 & 16.57 & $9.30 \times 10^{6}$ \\
3 & $1.00 \times 10^{7}$ & 3 & 7.19 & $4.00 \times 10^{6}$ \\
4 & $2.00 \times 10^{7}$ & 6 & 31.66 & $2.63 \times 10^{7}$ \\
5 & $1.25 \times 10^{4}$ & 6 & 4.11 & $1.40 \times 10^{6}$ \\
6 & $1.25 \times 10^{4}$ & 3 & 1.98 & $5.00 \times 10^{5}$ \\
7 & $2.00 \times 10^{7}$ & 9 & 6.73 & $1.05 \times 10^{7}$ \\
8 & $1.00 \times 10^{7}$ & 9 & 4.66 & $7.90 \times 10^{6}$ \\
9 & $1.25 \times 10^{4}$ & 9 & 1.51 & $3.40 \times 10^{6}$ \\
10 & $1.00 \times 10^{7}$ & 6 & 17.33 & $9.10 \times 10^{6}$ \\
11 & $1.00 \times 10^{7}$ & 6 & 18.01 & $8.90 \times 10^{6}$ \\
12 & $2.00 \times 10^{7}$ & 3 & 14.71 & $1.16 \times 10^{7}$ \\
13 & $1.00 \times 10^{7}$ & 6 & 17.08 & $8.90 \times 10^{6}$ \\
\hline
\end{tabular}

ing their productions would minimize these problems to some degree. Although, the primary focus of this paper is to optimize the same factors for PG enzyme production, it is not always possible in solid-state fermentation to have these conditions optimized in one parameter, as it is here the case.

According to the ANOVA table (Table 2), the type of solid substrate and the inoculum were significant $(p<0.01)$ on the total spore production whereas only type of solid substrate was significant on enzyme synthesis under the studied ranges. The lack of fit was insignificant for both of responses indicating a good fit, between the model and the experimental data.

As it can be deduced from D-optimal design (Table 1) and one factor plot (Fig. 1a), crushed maize is much more suitable for maximum enzyme synthesis compared to the other two substrate sources. It produced approximately 4.33 and 1.85 times more enzyme than corncob and maize meal, respectively, estimated from Fig. 1a. In order to determine the interaction of incubation time and inoculum using crushed maize as solid substrate, response surface graphs as shown in Fig. $1 \mathrm{~b}$ were generated. These showed that high inoculum together with shorter incubation time would favour towards maximum PG enzyme synthesis. Since true maxima were not obtained yet, it was suggested that further optimization was required. Therefore crushed maize favouring the PG synthesis was chosen as solid substrate for further optimization discussed in next section.

\subsubsection{Second optimization step (central composite design)}

In the second optimization step, the type of solid substrate as crushed maize was kept constant based on the results of the first optimization step. The two factors, inoculum $\left(X_{1}\right)$ and incubation time $\left(X_{2}\right)$ were optimized with respect to the two responses (PG activity and spore count) using $2^{2}$ face centered central composite design (Table 3 ). In order to get normally distributed response data, natural logarithm transformation to the PG activity and spore count were applied.

The results of ANOVA (tables not shown) for all two responses (PG activity and spore count) revealed that the individual models were highly significant $(p<0.001)$. All linear effects, interaction effect and quadratic effects were significant on PG activity. The coefficient of determinations were 0.9963 and 0.9860 for enzyme and spore count, respectively, indicating a good agreement between experimental and predicted values which can explain up to $99.63 \%$ and $98.60 \%$ variability of the responses. The "predicted $R^{2}$ " of 0.9669 and 0.8886 for each of the responses (in the same order as above) were in reasonable agreements with the "adj. $R^{2}$ " of 0.9937 and 0.9775 . The adjusted $R^{2}$ corrects the $R^{2}$ value of the sample size and for the number of terms in the model. Regression coefficients used in the final empirical models for both responses in terms of two factors in coded units were given in Table 4.

According to the central composite design (Table 3) and response surface graphics of $X_{1}$ and $X_{2}$ 
Table 4

Regression coefficients used in the final empirical model for two response variables in terms of two factors in coded units in SSF

\begin{tabular}{lll}
\hline Regression coefficient & $\ln$ (PG enzyme activity) & $\ln$ (spore count) \\
\hline$\beta_{0}$ & 2.84 & 15.99 \\
$\beta_{1}$ & $0.92^{* * *}$ & $1.27^{* * * *}$ \\
$\beta_{2}$ & $-0.25^{* * *}$ & $0.37^{* * *}$ \\
$\beta_{12}$ & $-0.13^{*}$ & $-0.36^{* *}$ \\
$\beta_{11}$ & $-0.38^{* * *}$ & $-0.33^{*}$ \\
$\beta_{22}$ & $-1.05^{* * *}$ & $-0.52^{* *}$
\end{tabular}

Subscripts: 1 , inoculum and 2 , incubation time.

* Significant at 0.05 level.

** Significant at 0.01 level.

*** Significant at 0.001 level.
(Fig. 2a), maximum PG activity (30.55 U/g solid) could be attained at higher inoculums $\left(2 \times 10^{7}\right.$ total spores) and at an optimum incubation period of 5.34-5.5 days. This activity was almost six times higher compared to the first optimization step (5.1 U/g solid) performed with the same substrate (Fig. 1a).

The response surface graphs (Fig. 2b) depicting the interaction of $X_{1}$ and $X_{2}$ indicated that with high inoculums $\left(2 \times 10^{7}\right.$ total spores $)$ and an incubation period of 5.5-6.41 days, maximum amounts of spore generation $\left(2.23 \times 10^{7} \mathrm{spore} / \mathrm{ml}\right)$ was obtainable. Therefore, second optimization procedure (Fig. 2b) resulted into 2.65 times more spore production using
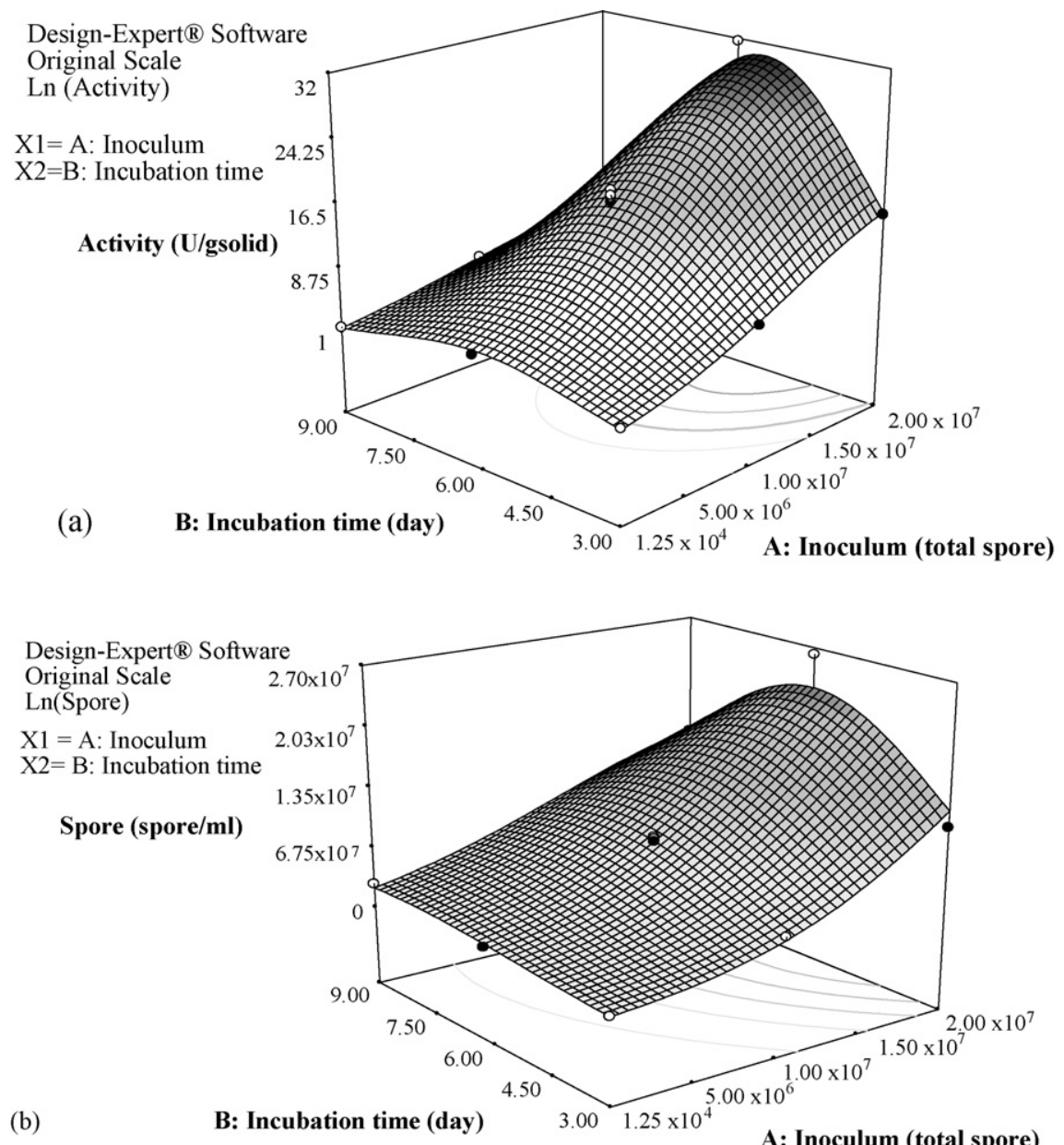

Fig. 2. Results of CCD: response surface plots showing the effects of inoculum and incubation time on (a) PG enzyme activity and (b) spore counts. 
Table 5

Validation experiments of the optimized conditions in SSF

\begin{tabular}{lllll}
\hline Running order & Inoculum (total spores) & Incubation time (day) & PG activity (U/g solid) & Spore (spore/ml) \\
\hline 1 & $2.00 \times 10^{7}$ & 5 & 26.12 & $2.19 \times 10^{7}$ \\
2 & $2.00 \times 10^{7}$ & 5.5 & 29.09 & $2.31 \times 10^{7}$ \\
3 & $2.00 \times 10^{7}$ & 6 & 27.42 & $2.10 \times 10^{7}$ \\
\hline
\end{tabular}

the same substrate (crushed maize). (A maximum of $8.4 \times 10^{6} \mathrm{spore} / \mathrm{ml}$ was obtained in the first optimization step, data in Table 1 were converted to spore $/ \mathrm{ml}$, taking into account the filtration volumes for comparison.) Therefore, there was a considerable level of increase in the spore counts. If one wants to generate spores in addition to enzyme production, these results would be indicative for the necessary conditions to apply.

\subsubsection{Validation of the model}

The optimum conditions predicted by the invidual models of RSM for each of the responses were almost in the same range of $X_{1}=2 \times 10^{7}$ total spores and $X_{2}=5.34-6.4$ days. In order to validate individual models, three different incubation times (5, 5.5 and 6), within the predicted ranges were chosen with an inoculum of $2 \times 10^{7}$ total spores and experiments were conducted (Table 5). The predicted

Table 6

Central composite design and experimental results of PG enzyme activity in SmF

\begin{tabular}{|c|c|c|c|c|c|}
\hline Running order & Maltrin (g/l) & $\operatorname{CSL}(\mathrm{g} / \mathrm{l})$ & Agitation speed (rpm) & Inoculum (total spore) & Activity (U/ml) \\
\hline 1 & 50 & 8.75 & 225 & $5.00 \times 10^{5}$ & 2.21 \\
\hline 2 & 25 & 2.5 & 150 & $7.50 \times 10^{5}$ & 0.76 \\
\hline 3 & 25 & 15 & 150 & $2.50 \times 10^{5}$ & 1.57 \\
\hline 4 & 25 & 15 & 300 & $2.50 \times 10^{5}$ & 1.89 \\
\hline 5 & 75 & 15 & 300 & $7.50 \times 10^{5}$ & 4.81 \\
\hline 6 & 50 & 8.75 & 300 & $5.00 \times 10^{5}$ & 2.98 \\
\hline 7 & 50 & 8.75 & 225 & $5.00 \times 10^{5}$ & 3.55 \\
\hline 8 & 25 & 15 & 150 & $7.50 \times 10^{5}$ & 0.32 \\
\hline 9 & 75 & 15 & 150 & $7.50 \times 10^{5}$ & 4.19 \\
\hline 10 & 75 & 2.5 & 150 & $7.50 \times 10^{5}$ & 5.49 \\
\hline 11 & 25 & 2.5 & 300 & $2.50 \times 10^{5}$ & 1.72 \\
\hline 12 & 50 & 8.75 & 225 & $5.00 \times 10^{5}$ & 2.49 \\
\hline 13 & 25 & 2.5 & 300 & $7.50 \times 10^{5}$ & 2.71 \\
\hline 14 & 75 & 2.5 & 300 & $7.50 \times 10^{5}$ & 7.35 \\
\hline 15 & 50 & 8.75 & 225 & $5.00 \times 10^{5}$ & 3.13 \\
\hline 16 & 75 & 15 & 150 & $2.50 \times 10^{5}$ & 4.35 \\
\hline 17 & 50 & 8.75 & 225 & $5.00 \times 10^{5}$ & 1.69 \\
\hline 18 & 50 & 8.75 & 150 & $5.00 \times 10^{5}$ & 1.67 \\
\hline 19 & 75 & 15 & 300 & $2.50 \times 10^{5}$ & 3.36 \\
\hline 20 & 50 & 8.75 & 225 & $7.50 \times 10^{5}$ & 2.43 \\
\hline 21 & 25 & 8.75 & 225 & $5.00 \times 10^{5}$ & 0.91 \\
\hline 22 & 75 & 2.5 & 300 & $2.50 \times 10^{5}$ & 8.62 \\
\hline 23 & 50 & 2.5 & 225 & $5.00 \times 10^{5}$ & 4.35 \\
\hline 24 & 25 & 2.5 & 150 & $2.50 \times 10^{5}$ & 1.58 \\
\hline 25 & 75 & 2.5 & 150 & $2.50 \times 10^{5}$ & 4.57 \\
\hline 26 & 25 & 15 & 300 & $7.50 \times 10^{5}$ & 0.29 \\
\hline 27 & 50 & 8.75 & 225 & $2.50 \times 10^{5}$ & 3.63 \\
\hline 28 & 50 & 8.75 & 225 & $5.00 \times 10^{5}$ & 1.90 \\
\hline 29 & 50 & 15 & 225 & $5.00 \times 10^{5}$ & 2.15 \\
\hline 30 & 75 & 8.75 & 225 & $5.00 \times 10^{5}$ & 5.58 \\
\hline 31 & 50 & 8.75 & 225 & $5.00 \times 10^{5}$ & 2.52 \\
\hline
\end{tabular}


enzyme activity (30.55 U/g solid) and spore count $\left(2.23 \times 10^{7} \mathrm{spore} / \mathrm{ml}\right)$ were very close to the actual values obtained experimentally $(29.09 \mathrm{U} / \mathrm{g}$ solid and $2.31 \times 10^{7}$ spore/ml, respectively). This showed very good compatibility of the model with experimental data. The overall optimum region as specified by the desirability plot, considering the two responses together, overlayed with the individual optima.

\subsection{Optimization of submerged fermentation}

Factors like carbon and nitrogen sources and their concentrations have always been of great interest to the researchers in the industry for the low cost media design especially when strains lacking information on their growth requirements, are under consideration, such as the case here (Tari et al., 2006). It is also known that $30 \%$ to $40 \%$ of the production cost of industrial enzymes is estimated to be the cost of growth medium (Joo et al., 2002). These sources together with factors like agitation speed and inoculum, besides their effect on the product formation, have been determined to play significant role in the determination of the final morphology of the culture (Olsvik et al., 1993). Therefore, it is of great significance to optimize the conditions for cost-efficient enzyme production.

Based on this a face-centered central composite design with 31 experiments was performed. The respective low and high levels with the coded levels in parentheses for the factors were defined as $25(-1)$

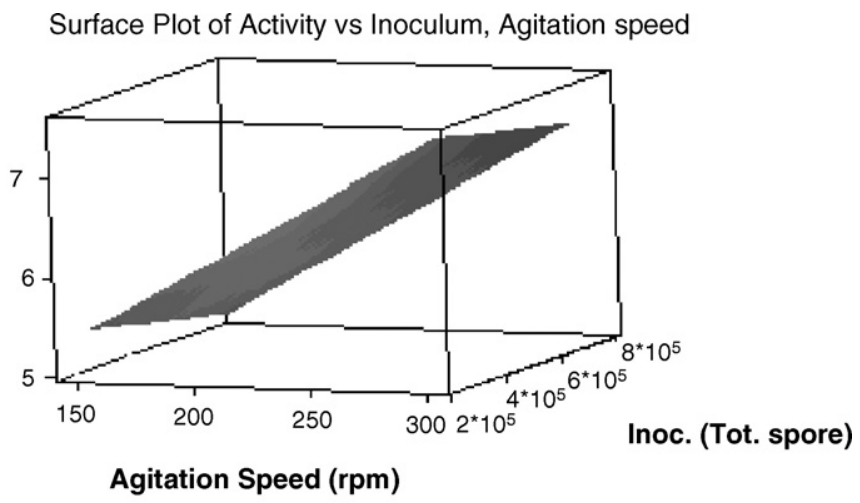

Hold values

Maltrin $75 \mathrm{~g} / \mathrm{l}$

CSL $2.5 \mathrm{~g} / 1$

Activity (U/ml)

(b)

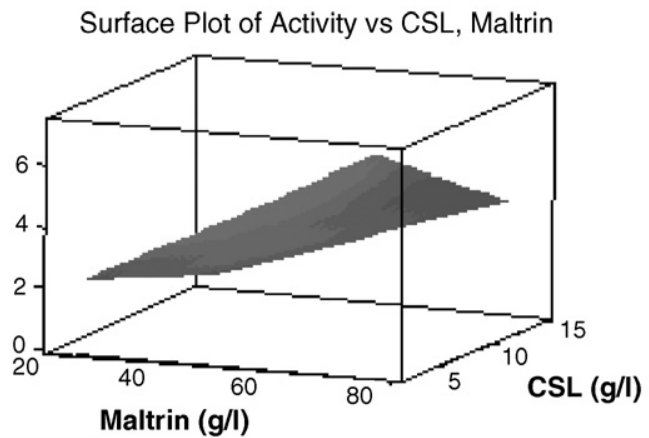

Hold values

Agitation speed $300 \mathrm{rpm}$

Inoculum $75^{*} 10^{\text {s }}$ total spore

Fig. 3. Results of CCD in SmF: response surface plots showing the effects of (a) maltrin and CSL, (b) inoculum and agitation speed on PG enzyme activity. 
Table 7

Regression coefficients used in the final empirical model for PG activity in terms of coded units in $\mathrm{SmF}$ and their significance levels

\begin{tabular}{lcc}
\hline Terms & Regression coefficients & $p$-Value \\
\hline Constant & 3.0580 & 0.000 \\
Maltrin & 2.0322 & 0.000 \\
CSL & -0.7906 & 0.000 \\
Agitation speed & 0.5136 & 0.011 \\
Inoculum ratio & -0.1619 & 0.395 \\
Maltrin $\times$ CSL & -0.4130 & 0.048 \\
Agitation speed $\times$ CSL & -0.5048 & 0.018 \\
\hline
\end{tabular}

$S=0.7937 ; R^{2}=86.6 \% ; R^{2}(\operatorname{adj})=.83.2 \%$.

and $75(+1) \mathrm{g} / \mathrm{l}$ for maltrin, $2.5(-1)$ and $15(+1) \mathrm{g} / \mathrm{l}$ for CSL, $150(-1)$ and $300(+1) \mathrm{rpm}$ for agitation speed, and $2.5 \times 10^{5}(-1)$ and $7.5 \times 10^{5}(+1)$ total spore for inoculum. The experimental runs with their response variable (PG activity) are presented in Table 6. After treatment combinations, the response data for maltrin and CSL, agitation speed, inoculum and the interaction terms of CSL and agitation speed, and the interaction terms of maltrin and CSL yielded significant $(p<0.05)$ terms with respect to PG activity. The coefficients of the model in coded units and their significance levels are presented in Table 7. The adjusted $R^{2}$ of the model was $83.2 \%$ for PG with an insignificant lack of fit indicating a good fit between the model and the experimental data. According to the central composite design (Table 6) and the response surface graphs of maltrin, CSL and agitation speed (Fig. 3a and b) maximum PG activity $(7.4 \mathrm{U} / \mathrm{ml})$ could be achieved at higher maltrin and lower CSL concentrations and at higher agitation speeds. The inoculum was insignificant under ranges studied. In order to validate the model, experiments at high maltrin $(75 \mathrm{~g} / 1)$, low CSL ( $2.5 \mathrm{~g} / \mathrm{l})$ with an inoculum of $2.5 \times 10^{5}$ total spore at $300 \mathrm{rpm}$ agitation were performed and a PG activity of $8.4 \mathrm{U} / \mathrm{ml}$ was obtained. This value was slightly higher compared to the model prediction. Therefore, these conditions were the optimized conditions of SmF under the ranges studied where maximum PG could be attained.

\subsection{Comparison of submerged to solid-state fermentation}

The maximum PG activity attained by the optimized condition in SSF (1.26 U/mg biomass converted using $29.09 \mathrm{U} / \mathrm{g}$ solid) provided 1.48 times more activ- ity compared to the maximum PG activity obtained under the optimized conditions in $\mathrm{SmF}(0.84 \mathrm{U} / \mathrm{mg}$ biomass converted using $8.4 \mathrm{U} / \mathrm{ml}$ ). This result points out the possible profitability of SSF over SmF with respect to enzyme yield.

In the comparison of the current results with the literature studies conducted on pectinase production using various substrates with different fungal organisms in SSF, reveals that the enzyme activity obtained in this study, is within the range of those results (Martins et al., 2002; Martin et al., 2004; Silva et al., 2002; Silva et al., 2005). The enzyme activity obtained from $A$. sojae used in this study was three times higher than the activity obtained by A. niger which is known to be used commercially in the production of pectinase when compared to a study performed by Martin et al. (2004). In their study they used $90 \%$ wheat bran and $10 \%$ sugar cane bagasse medium and obtained polygalacturonase activity in the range of 9.0-11.4 U/g solid (Martin et al., 2004). The activity result obtained here was also four times higher compared to another study done by Maldonado using A. niger in the production of pectinase in SSF (Maldonado and Strasser de Saad, 1998). Although, none of these studies could provide direct comparison, since not all of the conditions were identical, it will still provide a rough overview. These comparisons can be used as an indication that $A$. sojae can be a good candidate for the commercial production as well. This is an another important result of this study, introducing a new strain for the production of an enzyme with industrial significance, which has not been considered for this purpose so far.

According to a review paper reported on the solidstate fermentation to food industry, it is reported that pectinase production by SSF is more productive than $\mathrm{SmF}$ and that the pectinases produced by this method show more stable properties, such as higher stability to $\mathrm{pH}$ and temperature and are less affected by catabolic repression (Couto and Sanroman, 2005). Considering this, it is obvious that SSF will provide a new trend towards the production of enzymes with industrial significance and expand new areas of development for process design.

\section{Conclusion}

Overall this study demonstrated that $A$. sojae which has not been considered so far, can be a good 
candidate for the production of polygalacturonase, an enzyme with highly commercial value, in SSF. Using a statistical tool (RSM) it was possible to point out, the interactive effect of solid substrate, inoculum and incubation time which are highly significant in SSF, on the response variables of PG activity and total spore formation. The optimized regions obtained through this technique will give the enduser, whether this might be in the enzyme industry, food industry, flexibility to decide on the ranges to be used depending on the response of interest. It will also provide the conditions required (within the scope of this study) for spore generations for $\mathrm{SmF}$ wherever this organism might be used. Furthermore, this study demonstrates the comparison of the SSF to SmF with respect to PG activity. It showed that SSF is more profitable and that the future would be in the direction of reconsidering the applications of this technique, possibly opening up new areas of development in this field. Moreover, by providing specific information regarding the growth requirements particularly applicable to this organism, it will partly fill the gap in the literature that has been lacking so far.

\section{Acknowledgement}

Financial support of Izmir Institute of Technology through the project IYTE 2004, 04 is gratefully acknowledged.

\section{References}

Bai, Z.H., Zhang, H.X., Qi, H.Y., Peng, X.W., Li, B.J., 2004. Pectinase production by Aspergillus niger using wastewater in solidstate fermentation for eliciting plant resistance. Bioresour. Technol. 95, 49-52.

Castilho, L.R., Medronho, R.A., Alves, T.L.M., 2000. Production and extraction of pectinases obtained by solid-state fermentation of agro-industrial residues with Aspergilus niger. Bioresour. Technol. 71, 45-50.

Couto, S.R., Sanroman, M.A., 2005. Application of solid-state fermentation to food industry-a review. J. Food Eng. 22 (3), 211-219.

Gogus, N., Tari, C., Oncu, S., Unluturk, S., Tokatli, F., 2006. Relationship between morphology, rheology and pectinase production by Aspergillus sojae ATCC 20235 in submerged cultures. Biochem. Eng. J., submitted for publication.

Gonzales, G.V., Torres, E.F., Aguilar, C.N., Gomez, S.J.R., Godinez, G.D., Augur, C., 2003. Advantages of fungal enzyme production in solid-state over liquid fermentation systems. Biochem. Eng. J. $13,157-167$.

Jayani, R.S., Saxena, S., Gupta, R., 2005. Microbial pectinolytical enzymes: a review. Process Biochem. 40, 29312944.

Joo, H.S., Kumar, G.C., Park, G.C., Kim, K.T., Paik, S.R., 2002. Optimization of the production of an extracellular alkaline protease from Bacillus horikoshii. Process Biochem. 38, 155159.

Knapp, J.S., Howell, J.A., 1980. Solid Substrate Fermentation: Topics in Enzyme and Fermentation Biotechnology. A Wiseman Ellis Horwood Ltd., Chichest, England, pp. 85143.

Kunamneni, A., Singh, S., 2005. Response surface optimisation of enzymatic hydrolysis of maize starch for higher glucose production. Biochem. Eng. J. 27, 179-190.

Layman, P., 1990. Promising new markets in emerging for commercial enzymes. Chem. Eng. News 68, 17-18.

Maldonado, M.C., Strasser de Saad, A.M., 1998. Production of pectin esterase and polygalacturonase by Aspergillus niger in submerged and solid-state systems. J. Ind. Microbiol. Biotechnol. 20, 34-38.

Manonmani, H.K., Sreekantiah, K.R., 1987. Studies on the conversion of cellulase hydrolysate into citric acid by Aspergillus niger. Process Biochem. 22, 92-94.

Martins, E.S., Silva, D., Da Silva, R., Gomes, E., 2002. Solid-state production of thermostable pectinases from thermophilic Thermoascus urantiacus. Process Biochem. 37, 949954.

Martin, N., Souza, S.R., da Silva, R., Gomes, E., 2004. Pectinase production by fungal strains in solid-state fermentation using agro-industrial bio products. Braz. Arch. Biol. Technol. 47, 813819.

Olsvik, E., Tucker, K.G., Thomas, C.R., Kristiansen, B., 1993. Correlation of Aspergillus niger broth rheological properties with biomass concentration and the shape of mycelial aggregates. Biotechnol. Bioeng. 42, 10521946.

Panda, T., Naidu, G.S.N., Sinha, J., 1999. Multiresponse analysis of microbiological parameters affecting the production of pectolytic enzymes by Aspergillus niger: a statistical view. Process Biochem. 35, 187-195.

Pandey, A., Benjamin, S., Soccol, C.R., Nigam, P., 1999. Solid-state fermentation for the production of industrial enzymes. Curr. Sci. 77, 149-162.

Pandey, A., Soccol, C.R., Nigam, P., Soccol, V.T., 2000. Biotechnological potential of agro-industrial residues. I. Sugar cane bagasse. Bioresour. Technol. 74, 6980.

Sangeetha, P.T., Ramesh, M.N., Prapulla, S.G., 2004. Production of fructosyl transferase by Aspergillus oryzae CFR 202 in solid-state fermentation using agricultural by-products. Appl. Microbiol. Biotechnol. 65, 530-537.

Silva, D., Martins, E.S., Da Silva, R., Gomes, E., 2002. Pectinase production by Penicillium viridicatum RFC3 by solid-state fermentation using agricultural wastes and agro-industrial by-products. Braz. J. Microbiol. 33, 318-324. 
Silva, D., Tokuioshi, K., Martins, E.S., Silva, R.D., Gomes, E., 2005. Production of pectinase by solid-state fermentation with Penicillium viridicatum RFC3. Process Biochem. 40, 28852889.

Spangnuolo, M., Crecchio, C., Pizzigalo, M.D.R., Ruggiero, P., 1997. Synergistic effects of celluloytic and pectinolytic enzymes in degrading sugar beet pulp. Bioresour. Technol. 60, 215222.

Tari, C., Genckal, H., Tokatli, F., 2006. Optimization of a growth medium using a statistical approach for the production of an alkaline protease from a newly isolated Bacillus sp. L21. Process Biochem. 41, 659-665. 